\title{
Role of Religious Moderation in Alleviation of Extremism in Islamic Teachings Perspective
}

\author{
*Dr. Muhammad Arshad \\ **Dr. Naseem Mahmood
}

\section{Abstract:}

Human being is observing two different attitudes throughout the world, one of them is extremism and other is moderation. This research paper is about the religious moderation and its role in alleviation of extremism which is dangerous for the humanity. Some aspects of this topic such as concepts and some related points of moderation and extremism, religious moderation in believe matters, worship and dealings, ethics, legal and social matters have been discussed in detail in Islamic perspective. Islamic moderation role in alleviation of extremism in these matters has been discussed with the evidences of Qur'anic verses and the traditions of Holy Prophet (PBUH). This study will help the human community to adopt the balanced attitude in the daily routine matters which may make the humanity useful and helpful rather than being the dangerous and harmful.

Islam is a world religion which provides the universal rules and regulations for the balanced human life. Its teachings are not only comprehensive but also worth practicable for every nation based on believes territory, language or specific theories. It provides the guidelines for the religion, social, economic or natural science based researchers of any era of this earth planet. Extremism is an international issue for the human being and it cannot be especially related to any specific religion or the group of people. Whole the world is harassed and scared because of extremism fear. Muslim community all over the world is claimed and blamed to be involved in such activities. Who is the pioneer and when started this tragedy is a debatable issue which proves to be far from the religion of Islam. The theme of this research paper is that how the Diem of extremism can be snubbed through religious moderation and which kind of role religion plays in its alleviation? It is a recognized fact that the moderation is a basic principle of Islam. One can avoid many vices and wrongful acts even the extremist attitude by adopting the Islamic phenomenon of moderation. This research paper may be dividing in to the following topics:

\footnotetext{
*Associate Professor, Govt. Postgraduate College, Shakargarh

**Assistant Professor, Govt. Allama Iqbal Postgraduate College, Sialkot
} 
1. Concept of moderation and extremism;

2. Religious moderation in believe matters;

3. Religious moderation in worships and dealings;

4. Religious moderation in judicial matters

5. Religious moderation in social matters; and

6. Moderation: The best action.

Detail of the above mentioned points is as follow:

\section{Concept of moderation and extremism:}

Before proceeding to the detail of the topic it is necessary to know the meaning of moderation and moderation and that is as under:

\subsection{Concept of Moderation:}

"Moderation is the quality of being reasonable and not being extreme. Similarly, political, religious, etc. ideas and actions which are normal, reasonable or acceptable to most of the people are called moderate ideas."

According to this concept of moderation it is necessary for an idea or action that it must be normal, reasonable and the most important element of these definitions is that it must be acceptable to the people. It does not mean that if an idea or theory is against the belief or thought of a group of people it may not be called the moderate believe it theory but it means that if though some people may not accept it but it should be reasonable and balanced one and beneficial to the human being. The religious moderation is the only way to diminish this threat and its negative effects. The word moderation means "the process of elimination or lessening extremes. It is used to ensure normality throughout the medium on which it is being conducted.",

\subsubsection{Easiness is a Sign of Moderation:}

The basic spirit of Islamic teachings is easiness and facilitation. This Islamic purpose can be achieved through moderate attitude in all aspects of life. Qur'an describes the principle related to moderation in the words:

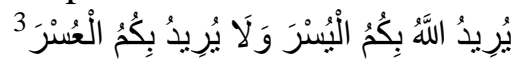

"Allah intends for you ease and does not intend for you the hardship" 
This Qur'anic verse expresses that the Islamic slogan is to facilitate and provide the ease for human being. If a person is patient or is in journey, then the obligatory fasting may be postponed for the days after Ramadan and the missing figure of the fasting is to fulfilled after this holy month and same is the position in prayers as mentioned earlier. Islamic jurists derived a Sharī'ah maxim from this verse that:

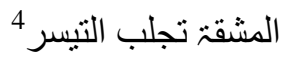

"Hardness causes easiness"

It is clear that where there is any problem or difficulty there is easiness in Islam. So easiness is the well-established objective of Islam. It is proved fact that there is no propel for which Islam does not provide the remedy. When Islam provides the list of prohibited foods it also allows its necessary use for the people who find nothing to eat and to save their lives and there is fear of death if they don't eat or drink the prohibited one. ${ }^{5}$ Holy Prophet also adopted this principle in his daily actions as mother of Muslims and the wife the Prophet (PBUH) Hazrat Ayesha stated that "whenever Holy Prophet (PBUH) was given chance between two things, he always opted the easier one if it was not sin."

These Islamic teachings are the clear message for its followers that Islam is to provide eases not the hardships. Also Islam always considers the human problems and does not imposes its ordered on the stressed ones. This practice can be observed in moderate religion only and that is Islam at present all over the world.

\subsection{Concept of Extremism:}

The concept of moderation clearly elaborates the concept of extremism as it opposite to its concept. So "the ideas and actions of any nature which are not acceptable to the people are called extremism. The important element of any idea or action to be considered of the nature of the term under discussion is that it must be wrongful and harmful act causing the harassment and destruction of the human nations. This term literally means "the quality or state of being extreme or the advocacy of extreme measures or views. The term is primarily used in a political or religious sense, to refer to an ideology 
that is considered to be far outside the mainstream attitude of society it can also be used in an economic context."

\subsubsection{Extremism not Acceptable in Islam:}

Islam totally neglects the extremism and does not any activity supporting to it so is the reason that Qur' $\bar{\alpha}$ n orders to fight with the persons causing the persecution in the society and orders to continue this fight till its rooting out. ${ }^{8}$ This extremism is not allowed even in prayers as it is clear from the Sunnah of Prophet $(\mathrm{PBUH})$ that entered the mosque and noticed a rope stretched between two columns. What is this rope for? He was told: This is Zainab's rope. During her voluntary prayer she begins to feel tired she grasps it for support. The Holy Prophet (PBUH) said:

$$
\text { حلوه ليصل احدكم نشاط,، فاذا فتر فليرقد } 9
$$

"Undo it, you should pray so long as you feel alert. When you feel tired you should go to sleep"

So it is well established fact that extreme attitude is not acceptable even in prayer. According to the teachings of Holy Prophet (PBUH) the daily life of a Muslim must be based on moderation and no one is allowed to observe the extreme attitude in his life.

\subsubsection{Prophetic Condemnation of Extremists:}

Islamic teachings, as discussed above, are to eliminate the extremism so is the reason that Holy Prophet (PBUH) says in its condemnation:

$$
\text { هلى المستنطعون قالها ثلاثا }
$$

"Ruined are those who insist on hardship in matters he repeated it thrice."

According to this saying violence committing persons will never live long but ultimately they will be ruined up and eliminated. It also expresses that the violence is mean of destruction in every field. It also elaborates that balance and moderation are necessary for success and solution of the problems. 


\subsection{Availability of Moderate Community in Every Era:}

It is the fact that moderate community exists all over the world in every religion and in every group of people even in Jews and Christian. Qur'an narrates this fact as:

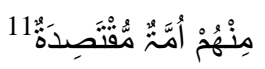

"Moderate community exists among st them"

We become extremist, when we are declaring that all the other sects are baseless and have nothing to stand on, just like Jews and Christians who claimed against each other that they have nothing to stand on.

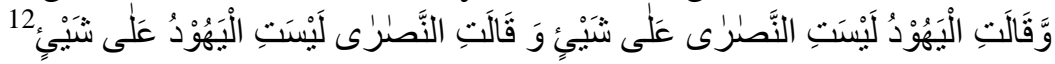

"Jews said that Christians have nothing to stand on and the

Christians said that Jews have nothing to stand on"

It is clear from the words of the Holy Qur' $\bar{\alpha}$ that the moderate people are available in every religion who think positive and act for the betterment of human being and such kind of people are beneficent for others.

\subsection{Scope of Islamic Religion:}

The problem of extremism in current era is succumbed with religion and specially with the religion of Islam while the followers of the last Prophet Muhammad are practical moderates, so is the reason that they are called Ummat-e-Wast. This title has been given to these followers by the divine book Qur' $\bar{\alpha}$ as used in its text and that is:

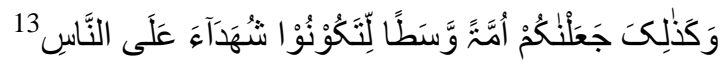

"And in the same way, we made you the best and moderate ummah, so that you may bear witness to the people."

Allah Almighty has declared in His own words that the Muslim ummah is a group of people who are tolerant, moderate and balanced. So being a member of Muslim ummah we have to adopt moderation and justice for the alleviation of extremism

Qur' $\bar{\alpha}$ clearly discussed the reality of the people behavior and their attitudes which caused the disturbance or its development. But when the human behavior converts to moderation they exit from the extremist community and 
become the member of moderate society. Moderation attitude leads to coexistence of followers of all the religions which is converting such societies into cosmopolitan religion societies. But unfortunately Muslim are being treated as extremists in the western society and on the bases of this misconception and their murder is being justified for the theory of "alleviate Islam and diminish Muslims from the world".

\section{Religious Moderation in Believe Matters:}

The fact is that Islam did not order its followers to impose their ideas on the opponents but its objective is only to preach the community as Allah Almighty addresses His Prophet that:

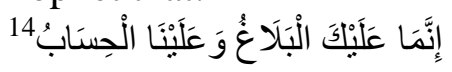

"Your duty is to communicate only and ours is reckoning"

The scholars and Ulema of Muslim world who are the inheritance of Holly Prophet are performing this duty in its true spirit and are communicating the message of Islam all over the world and they never tried to impose it on Non-Muslims. The main quality of Islam is that it tolerates others and never allows snubbing them but keeps the person free to adopt whatever religion he desires. Qur' $\bar{\alpha}$ has clearly described this points as:

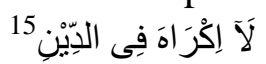

"There is no compulsion in Din"

So the embracing of Islam is not based on violence, pressure or compulsion. The person who feels the fear too his life is allowed to speak the denial words just to save his life and in this way he will not be answerable to Allah Almighty. Allah Almighty clearly mentions this point in Qur' $\bar{\alpha}$ as:

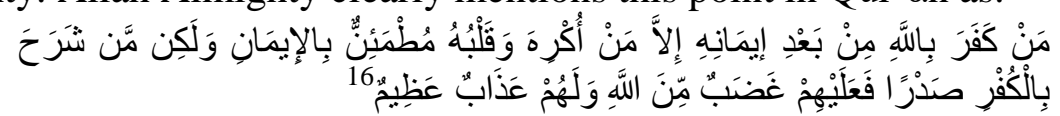

whose hearts is satisfied on Iman but he is compelled on it, but who clearly expresses the denial by core of heart, will face the eagerness of Allah Almighty and will bear the serve hardship"

Islam requires moderation in believes and does not stress any one to embrace it at any cost. But the fact is clear that the persons who embrace it and lead 
their lives according to its teachings will be entitled of Allah's mercy and the persons who pronounce the denial words just to save their lives will not be punished, this punishment will be only for the persons who leave Islam without ant coercion and runes away from its teachings after embracing it but without any coercion.

Islamic strategy is just to inform the people about the reality and not to stress the listener to follow or believe it. Allah almighty makes that fact in Qur' $\bar{\alpha} n$ with the wording that:

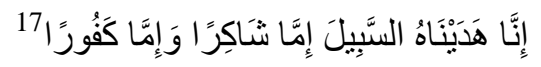

"We have guided him the path, whether he becomes the thankful or ungrateful"

This Qur' $\bar{\alpha}$ order mentions that the human being has not been stressed by Islam to obey any order provided by Islamic religion or to adopt its believe but he is free in his actions and believe and ultimately his life of hereinafter will be according to his worldly actions.

\section{Religious Moderation in Worships and Dealings:}

Moderation in worships and all types of the matters related to it can reduce much problems of the human society and makes it balanced and peaceful. There is a narration that three persons came to the wives of Holy Prophet (PBUH) to enquire about his worships style and quantity. After getting information about the same, they considered their worships much little as they were informed about the worship of Holy Prophet(PBUH) and decided to increase their worship quality. One of them said: I shell pray throughout the nights, the second one declared: I shall fast all the days shall not break, the third one announced: I shall keep away from the woman and shall never marry. When the Holy Prophet (PBUH) came to know their claims, he $\mathrm{f}$ lately rejected all these extremes and said: Behold by Allah, I fear Allah more than you, but I still keep fast and break it, keep up prayer and also sleep at nights and also marry and said at last the following words:

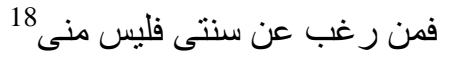

"So whoever turns away from my way is not from me" 
Practically being a part of society, he never tried to get rid of women or to be away from them, but he got married and produced daughters and sons and practically proved himself that all these dealings are not the interruptions for the betterment but it depends upon the individual dealings and attitudes and specially on the moderation in the attitude. The life of the Prophet (PBUH) clearly leaves a lesson for the humanity that the moderation in worship and family matter will lead the families and individuals to prove the ideal families and individuals. Marriages and worships does not require a person to be away from society but the moderate attitudes of the persons in this regard will make him the perfect one.

\subsection{Moderate Length in Prayer and Sermon:}

The purpose of human creation is the worship of Allah Almighty. The leaders of the collective worships like prayers and sermons are instructed to reduce its duration and make it shorter as possible and that is just to facilitate the community. This was the practice of Holy Prophet (PBUH) as it is clear by the tradition narrated by Hazrat Jabir bin Sumra as he used to perform prayers with Holy Prophet (PBUH) and his prayers and sermons were of moderate length. ${ }^{19}$ He justified this practice of Holy Prophet (PBUH) when he was asked about the same they Holy Prophet (PBUH) opted the moderate length of prayers and sermons just to avoid the burden, difficulty or hardship. In some mosques it has been observed, especially in Traweeh prayers, that the people avoid the mosques where Imams make the prayers lengthy and the just look to be in search of the mosques where the Imams shorten the recitation and other elements of prayers. This practice of the people expresses that the easy atmosphere in the worships causes to enhance the number of the worshipers and moderation in worships will definitely be effective and interest developing. If the Imams observe this aspect of teachings of Islam in collective prayers and sermons, Muslim community will definitely will revert to their creature Allah Almighty and will develop their servant relation to Him and through the strengthening of this relation they will be free from every grief and pain. Prayers are one type of remembrance of Allah Almighty and when the human remembers his creature He remembers him and it is the promise of Allah Almighty ${ }^{20}$ and 
through this remembrance he becomes satisfies as Allah Almighty states in Qur'ōn

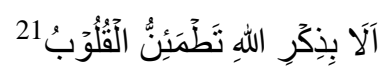

"Be alert, hearts are satisfied through the remembrance of Allah Almighty"

When the hearts are satisfied, it does not bother any problem or danger as it has been related to the fact who is problem solver and saver from every danger. So moderate prayers can cause the strengthen of human relation with Allah and this relation is the biggest wealth for the humanity.

\subsection{Teachings of Islam Based on Ease Not on Violence:}

The teachings of Islam are based on ease and facilitation and not on the violence. The Holy Prophet (PBUH) clearly elaborated it that:

$$
\text { ان الدين يسر } 22
$$

"The religion is easy"

Islam considers the problems of the community and changes its orders while considering the problems of the people. When a Muslim is unable to stand during his prayer he is allowed to perform it while sitting rather than standing and when he is unable to perform it in sitting position, he is allowed to perform it lying on his bed. Qur'ān mentions the easiness provided by Islam as:

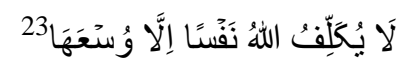

"Allah does not stress any soul beyond its endurance"

Holy Prophet (PBUH) advised his companions Ma'az Bin Jabal and Abu Moosa Asha'ri while appointing him the governors of Syria and Yaman that: provide the easiness and don't leave hardships, announce the good news and don't spread the hates" 24

All these facts clearly mention that the easy teachings of Islam cause the moderation instead of violence and these teachings are the main reason of ease and peace. 


\subsection{Moderation in Preaching:}

Islam is a balanced religion and it has provided the balanced teachings. Preaching is a religious need of every religion, but Islam does not allow the long timely or daily preaching causing the tiredness of people. If the people lose the interest they will not be able to get benefit of the teaching and it will be fruitless in any way. Prophet (PBUH) left his Sunnah for the guideline of the preachers of his Ummah that he fixed a day every week for preaching that it may not cause burden for the listeners and they may absolve and act upon the learned Islamic teaching easily. When the people required the consecutive preaching from Abdul Bin Masu'd, he replied that:

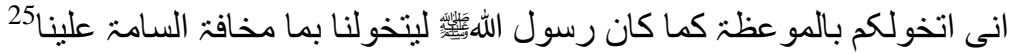

"I follow the same method in preaching as the Messenger of Allah (PBUH) adopted in his preaching to us due to fear of our boring."

This is the best example of balance and moderation. Although the preaching is the basic duty of the Holy Prophet (PBUH) but even though he avoided the daily preaching to avoid the burden and problem for his companions. Moderation in preaching is the Islamic wisdom which proves it the moderate religion in this regard also. If the balanced preaching is balanced, it will leave the long living affects for even society.

\section{Religious Moderation in Legal Matters:}

Law and order is the essential element of any state and of any government. There is no concept of state without law. Islam provides moderate teachings in this aspect also and the natures of this kind of teachings are that these are applicable in any regime and at any time. Following examples are the clear evidence of this fact:

\subsection{Religious Moderation: Source for Provision of Rights:}

Religious moderation is the main source for the provision of rights to the human being while on the other hand extremism is the reason for the deprivation of human being from their rights. Hazrat Abu Darda used to fast daily and say prayer the whole night, he had not any interest in the world. 
Hazrat Salman contradicted his view point and asked him only to perform prayer at the end of night and advised him with the words that:

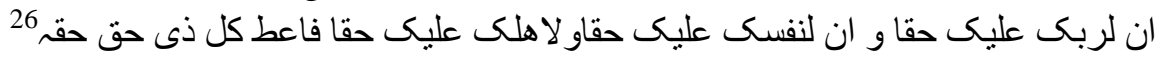

"Your Lord has a right on you, your soul has a right on you and your family has a right on you, so you should provide the rights of all those who have a right on you."

The next portion of this narration is that when Hazrat Salman discussed the rights of mother in presence of Holy Prophet (PBUH), he endorsed his statement and declared that Salman is very much right.

Abu Darda was no doubt involved in prayers but it has been established that in this tradition that the extremism even in prayers causes deprivation of rights. If a person keeps himself busy in fasting and prayers, he cannot perform the rights of his family and also of his body and soul, because he cannot sleep or take the proper rest for his body. So if you want to pay the all rights, rights of Allah Almighty, rights of your family, especially your mother, father, wife, sons, daughters, brothers, sisters and even the rights of your body, you have to opt the religious moderation which is the main source for the provision of all types of rights.

\subsection{Moderation in Retribution:}

Islam has prescribed Qisas in case of Qatl-i-amad (intentional murder). On the other-hand if the murderer is granted some remission by his brother, that should be executed fairly according to the law. Qur'an says:

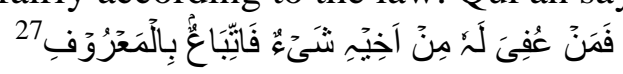

"He who has been granted some remission from his brother, should be fairly executed"

This remission in the execution of punishment will be called the moderation in retribution and if some murdered person has more legal heirs and any one of them pardons the murderer, retribution will not be executed but the blood money of their heirs will be paid to them.

Islamic penal system in such cases has provided three option to the victim's heirs. 
1. To get Qisas;

2. To give up the retribution and accept the blood money (Di-at); and

3. To pardon the murderer without receiving any blood money.

Practically observing these are the true moderate teachings of Islam in its penal system and nobody is crucially dealt in Islamic society. This is the reason that Islam is acceptable throughout the world, even in UN-Islamic societies also.

\section{Religious Moderation in Social Matters:}

Social aspect is a west field of any branch of knowledge. Islam provides the comprehensive guidelines in social aspect. Following are the few examples to understand the Islamic approach to this aspect:

\subsection{Moderation in Ethics:}

Essentially the Islamic teachings are the ethical teachings and the ethic is the major part of religion. Islamic ethical moderation related to the society can be observed as under:

\subsubsection{Moderation in Worlds Selection While Speaking:}

Islam provides the guidelines in words selection while speaking as Holly Prophet (PBUH) declared that:

$$
\text { المسلم من سلم المسلمون من لسانه ويده }
$$

"The Muslim is the person, people are saved from his tongue and hands"

and the main quality of Holly Prophet in the words Hazrat Abdullah Bin Amar is that:

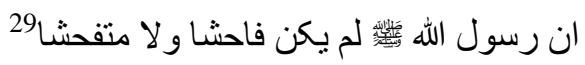

"Holy Prophet (PBUH) was neither obscene nor its inspired"

Qur'an also prohibits such dealing in its teachings as:

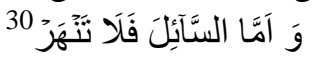

"Don't collapse the questioner"

Another kind of bad words is backbiting which is severely prohibited by Islam as Allah Almighty orders the followers of Islam:

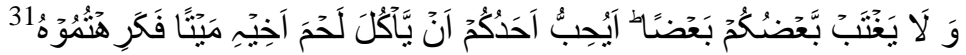


"Don't backbite each other, does any one of you will like to eat the flash of his dead brother, surely you will dislike it"

Islam provides the speaking norms that it should be short and comprehensive in words as it is famous saying that:

$$
\text { خير الكلام ما قل ودل32 - ت }
$$

"The best conversation is the shorter and comprehensive"

Prophetic speaking attitude is the clear evidence of this fact that he always used the shorter and comprehensive words in his conversation so is the reason that his companions never felt tired in his speeches and meetings.

These are few examples from Islamic teachings for talking etiquette which clarify the moderate talking attitude and it will make the society free from the bad intentions and disagreements which cause the destruction of the society.

\subsubsection{Moderation in pace and voice:}

Islam has directed to opt moderation in pace and voice. The Qur' $\bar{\alpha}$ nic words are as under:

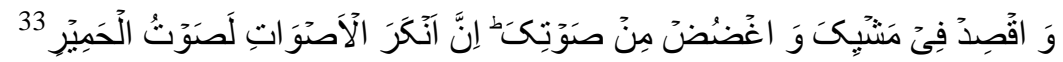

"And be moderate in your pace and lower your voice, indeed the most disagreeable of sounds is the voice of donkeys"

Needless loud voice is not in Islam but it provides the moderate teachings in voices while speaking as Allan almighty clearly states that:

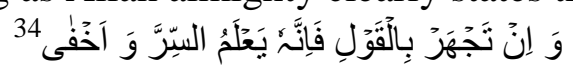

"If you speak loudly, Allah Almighty is aware of hidden and very invisible"

This Qur' $\bar{\alpha}$ order is to be implemented in its recitation as Allah Almighty says:

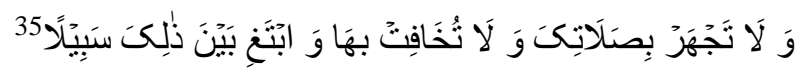

"And do not recite loudly in your prayer and not to quietly but keep between that an intermediate way" 
The moderation recitation of Qur'an causes ease, otherwise it causes disturbance in sleep, study, prayer of other peoples. So in Shabina, the Qur' $\bar{\alpha}$ has been recited loudly in loud-speakers in some places. According to this Qur'ānic principle, we have to opt moderate way of recitation of Qur'an, because the extreme even in recitation of Qur'an causes may harm the personal rights of people.

According to these verses, we have to be moderate in our pace upon the earth and also in voice. Our way of exultant walking causes to disgrace the others. Similarly our loud voice affects many people's personal rights as they feel disturbance in their routine matters.

\subsection{Moderation in Economics:}

Almost a common teaching of all the messenger of Allah Almighty was balanced economic and the moderate spending attitude and this habit uplifted the societies and alleviate the poverty amongst their followers.

\subsubsection{Prophetic Wordlists About Moderate Economics:}

Holy Prophet Muhammad has left his teachings related to every aspect of life and he expressly declares the moderate economic attitude as the $25^{\text {th }}$ part of Prophet-hood as he clearly mentioned that:

$$
\text { الاقتصاد جزء من خمستر عشرين جز ع من النبوة.36 }
$$

"Economic moderation is twenty-fifth part of Prophet-hood"

No doubt, to avail the blessings of Prophet-hood, humanity has to adopt the moderate-attitude in making their economic policies as well as long term and short term

Development programs which require the funds generated through any source.

\subsubsection{Moderation in Spending Money:}

Qur'an Hakim describes the quality of the people of Rehman that they are moderate in spending money. Qur'an provides the spending principle as:

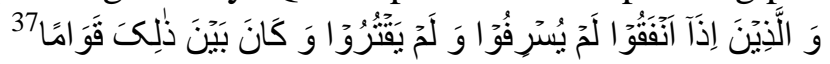


"And those who, do not excessively or sparingly spend, but hold a balance between these (extremes)"

It means that the servants of Allah Almighty, are those who when they spend, are neither wasteful expenditure nor miser but they hold a balanced attitude between the above mentioned two extremes in spending. When a man holds this balance he does not face any problem in his daily expenditures and other dealings and that is the practical picture of Holy Prophet's narration about moderation in spending of the money that:

$$
\text { ما عال من اقتصد } 38
$$

"One who exercises moderation will no more be poor"

Prophet (PBUH) expressly elaborated this fact in another narration that:

$$
\text { الاقتصاد فى النفقت نصف المعيشنت39 }
$$

"Moderation in expenditures is half economy"

The true management of economy is to manage the expenditures. Here the western life is totally repugnant to Islamic teachings where the public spend the income of whole week in week end luxuries in two days only. Opposite to west here in eastern countries most of the people earn the whole life but they don't enjoy their earnings but lead their poor life either for their children or only due to their mistral habit. So in Islamic teachings, the basic principle in economic field is to be moderate in spending. This principle beneficial to the individuals of family members, society and even the nation also. It is necessary to opt the moderation in spending money at individual, family and national levels to gain prosperity in economic field. The moderation attitude in spending the earnings can provide the result of poverty alleviation.

\subsubsection{Economic Moderation is Kind of the Prophet-hood Blessing:}

Almost a common teaching of all the messengers of Allah Almighty was balanced economic and the moderate spending attitude and this habit uplifted the societies and alleviated the poverty amongst their followers. Prophet Muhammad declared this economic attitude $25^{\text {th }}$ part of Prophet-hood as he clearly mentioned that:

$$
\text { الاقتصاد جزء من خمستر و عشرين جزء من النبوة40 }
$$

"Economic moderation is twenty-fifth part of Prophet-hood" 
No doubt, to avail the blessings of Prophet-hood, humanity has to adopt the moderate attitude in making their economic policies as well as long term and short term development programs which require the funds generated through any source.

\section{Moderation: the Best Action:}

While concluding the discussion, it is clear that the moderation is the best option for the better solution of the problems and to ease the hardship. This phenomenon has been provided by Holy Prophet (PBUH) as he said:

$$
\text { خير الاعمال اوسطها }
$$

"Best action is the moderate one"

This tradition provides the rule that every goodness lies in moderation and balanced way in every field of life i.e. behavior, worships, economic, preaching. Keeping in view, all the above mentioned arguments, it is clear that the religious moderate education plays an important role in alleviation of all kinds of extremism. It makes the society balanced one and produces the well-wishing, loving and caring nations. Without moderation approach nations, groups of people and even individuals are nothing. Allah Almighty linked His creation in balanced routine and every planet of His creation is observing its moderate and balanced routine and none of these planets dare to cross its limits. The day when this moderate routine of the world will be violated and left aside, that will be last day for this world which termed as the day of judgment, and that will be end of the world.

\section{Findings:}

The important findings of this article are as under:

1. Qur'ān says Muslim Ummah as moderate one.

2. Moderate community is available in every place and era.

3. Ruined are those who commit violence.

4. Religious moderation is consisting of spending, worships, sermon, pace, voice, retributive.

5. Moderation is necessary for success.

6. Good deeds lie in moderation.

7. Religious moderation causes provision of rights.

8. Moderation in economy is blessing of Prophet-hood.

9. Religious moderation has a significant role to alleviate the extremism. 


\section{References}

1 . Oxford Dictionary, 540, $8^{\text {th }}$ edition, Oxford university press.

2 . https://en.m.wikipedia.org,wiki

3. Al Baqara, 2/185

4 . Ibn-i-Nujaim, Al-Ashba-wn-Nazair, Vol:1, p:64

5. al-Baqara, $2 / 173$

${ }^{6}$. Bukhari, Al-Jame-ul-Sahih, Kitab-ul-Manaqib, Bab o Sifatul Nabi, Hadith No.3560

7 . Wikipedia, en.m.wikipedia.org/wik, searched on 03-04-2020 at 11:10 AM

8. Al-Anfal, 39/8

9 . Bukhari, Al-Jami, chapter Al-Salat, Hadith no:1150

10 . Muslim, Al-jami, chapter Al-Ilm, Hadith no:2670

11. Al-Maida, 5/66

12. Al-Baqara, 2/113

13. Al- Baqara, 2/143

14. Al-Ra'd, 13/40

${ }^{15}$. Al-Baqara, $2 / 256$

16. Al-Nahl, 16/106

${ }^{17}$. Al-Dahr, 76/3

18. Al-Muslim, Al-Jami, chapter Al-niqah, Hadith no.

19 . Muslim, Al-Jamih, Chapter Al-salaat, Hadith no:866, Dar-o-ihya-i-turas-il-arbi, Baroot

20. Al-Baqarah, 2/152

21 . Al-Ra'ad, 13/28

22. Bukhari, Al-Jami, chapter Al-Iman,Hadith no: 39

${ }^{23}$. Al-Baqarah, 2/286

24. Muslim, Al-Jame-ul-Sahih, Book:Al-Jihad Wal-Siar, Chapter:Amar Bil Taiseer Wa Tarkil Tanfeer, 3365

25 . Bukhari, Al -Jami, Al- Sahi, chapter,Al-ilm, Hadith no:69, Dar-i-tauq-i-nijat,

26. Bukhari, Al-Jami, Hadith no: 1968

27 . Al-Baqara, 2/178

28 . Bukhari, Kitab-ul-Eiman,Bab: Al-Muslim o Man Salimal Muslimoona Mn Lisanhi Wa yadehi, Hadith No. 10

29. Bukhari, Kitab-ul-Manaqib,Bab: Sifatul Nabi, Hadith No. 3559

30 . Al-Dhuha, 93/10

31 . Al-Hujurat, 49/12

32. Louis Ma'luf, Al-Munjad fi al-lughah wa-al-a'lam, $11^{\text {th }}$ Edition, 1983, Darula Mashriq, Bairoot, P:985

33 . Luqman, 31/19

34 . Taha, $20 / 7$

35. Al- Isra, 17/110

${ }^{36}$-Musnad-i-Ahmad, Hadith no:2698

37 . Al-Furqan, 25/67

38. Musnad-i- Ahmad, Hadith no:4269, Moasisa-tu-risala, $1^{\text {st }}$ edition, 1421 AH/2001 AD

39 . Tabrani, Al-Mujam-ul-Ausat, Hadith no: 6744, Dar-ul-haramain, Al Qahira

${ }^{40}$-Musnad-i-Ahmad, Hadith no:2698

41 . Bahqi, Shub-ul-iman, Hadith no:3604 